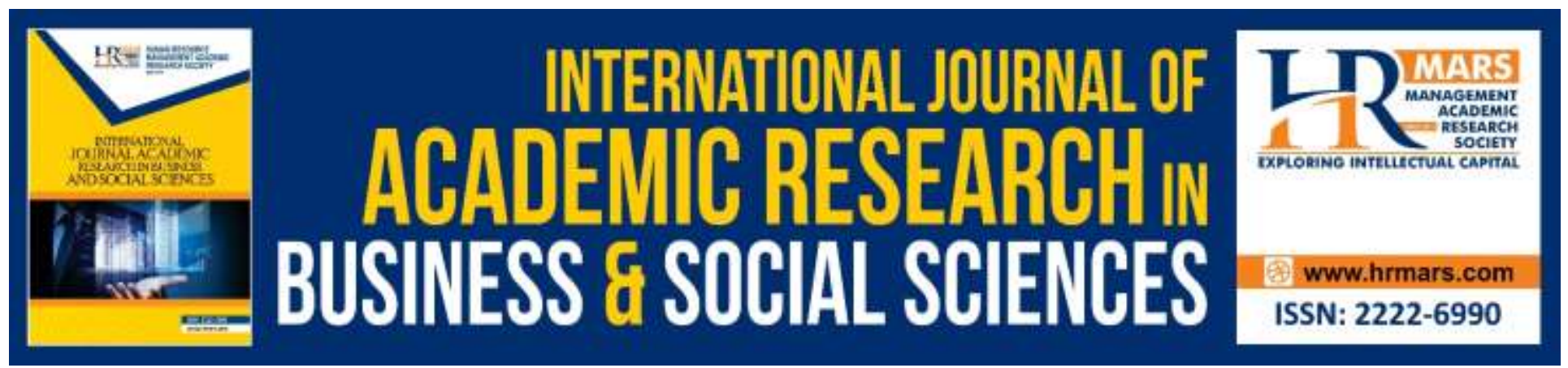

\title{
The Impact of Computerized Auditing in Reducing audit risks in Jordan
}

Khalil S. M. Abu Saleem, Ibrahim M. Oleimat

To Link this Article: http://dx.doi.org/10.6007/IJARBSS/v10-i6/7287

DOI:10.6007/IJARBSS/v10-i6/7287

Received: 23 April 2020, Revised: 27 May 2020, Accepted: 01 June 2020

Published Online: 06 June 2020

In-Text Citation: (Saleem \& Oleimat, 2020)

To Cite this Article: Saleem, K. S. M. A., \& Oleimat, I. M. (2020). The Impact of Computerized Auditing in Reducing audit risks in Jordan. International Journal of Academic Research in Business and Social Sciences, 10(6), 284298.

\section{Copyright: (C) 2020 The Author(s)}

Published by Human Resource Management Academic Research Society (www.hrmars.com)

This article is published under the Creative Commons Attribution (CC BY 4.0) license. Anyone may reproduce, distribute, translate and create derivative works of this article (for both commercial and non-commercial purposes), subject to full attribution to the original publication and authors. The full terms of this license may be seen

at: http://creativecommons.org/licences/by/4.0/legalcode

\section{Vol. 10, No. 6, 2020, Pg. $284-298$}

Full Terms \& Conditions of access and use can be found at http://hrmars.com/index.php/pages/detail/publication-ethics 


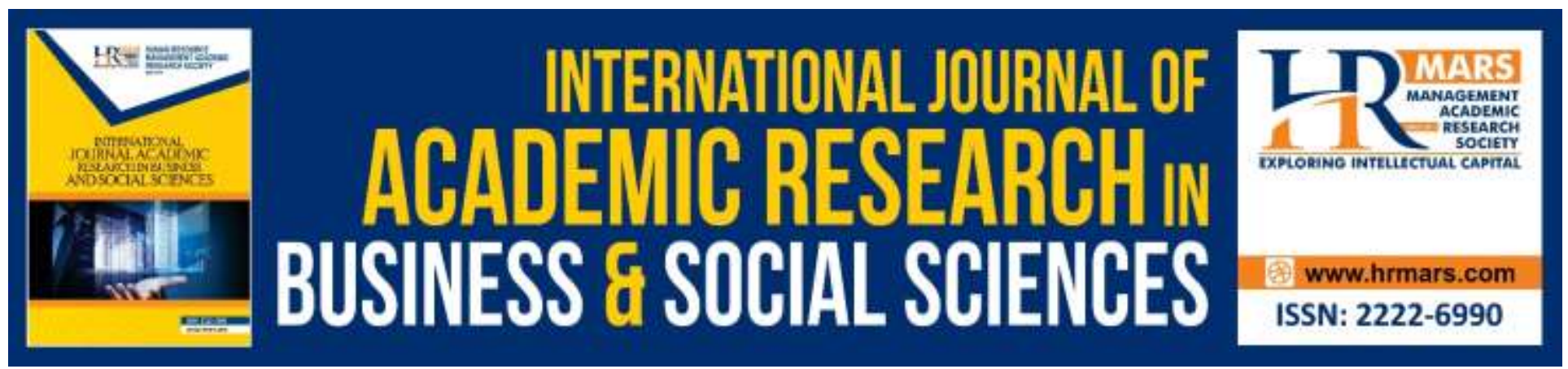

\title{
The Impact of Computerized Auditing in Reducing Audit Risks in Jordan
}

\author{
Dr. Khalil S. M. Abu Saleem \\ Associate Professor Accounting Faculty of Business \& Finance, the World Islamic Sciences \& \\ Education University (W.I.S.E), Amman, Jordan. \\ Email: kalilabosaleem@yahoo.com.
}

Ibrahim M. Oleimat

PhD Candidate Student of Accounting Department.

Email: i.oleimat@gmail.com

\begin{abstract}
Main focus of this study is to find out the significance of the variety of training programs for employees, as well as analyzing importance of accounting information systems within the computerized audit programs in reducing audit risks that associated with IT audit in Jordanian audit firms. The descriptive statistical method was used, a random sample of sector audit firms was selected and the sample consisted of (50), an accountant, had been randomly recruited to fill the questionnaire. The results indicated that the software used in the computerized audit ensure good financial performance, and the staff were well trained and fully qualified for working in the accounting and IT system that is related to the audit it found that the accounting information systems used in top ten Jordanian audit firms reduce risks relevant for accounting and ensure good performance. The study recommends the necessity of working to provide extensive protection programs for computerized audit firms, in addition to work on supporting staff training courses that increase the expertise of auditors to deal with the risks occurring.
\end{abstract}

Keywords: Audit Risks, Computerized Auditing, Audit Programs.

\section{Introduction}

The rapid development of information technology and accessibility to this information has led to the increasing number of users of this technology, either from individuals or companies. The cravings of the Companies to acquire and apply the computerized systems and programs contributed effectively in the effective deployment of information systems. The most essential field that has been impacted through this transform is the accounting, where the second half of the remaining century witnessed a rapid transition in the direction of using automated accounting statistics structures which lead to robust development in the performance of the clerical and accounting related task especially in the process of computerized auditing. 
But with the use of advanced technology exposure in the direction of different kinds of risks related to make Suring the safety as well as security of computerized accounting information systems. Additionally, the huge development within IT is not accompanied through a comparable development within the competencies as well as capacities of the human users of this technology. That creates a kind of risks which bound the efficiency and competence of the make use of these techniques (AlAkra, Abdel-Qader and Billah, 2016).

These risks or uncertainty need from the organizations to be extra conscious of the possible safety risks that intimidate the safety of their systems, the competence and efficiency of the software used in the process of computerized auditing, avoid these risks as well as decrease from its bad impacts as much as possible.

The IT infrastructure that is developed by any company plays a vital role in assisting in transforming accounting operations. Information technology has an important and significant role in process of gathering, using and storing useful information that is abridged and reported within financial reports. Large numbers of business are becoming progressively more relay on information technology by means of such components at the same time as fully included (IS) As well as the electronic document management flattering more common. It is commonly observed that during processing of accounting information employees make a lot of mistakes. In order to avoid such kind of mistakes steps can be taken like IT infra can be evolved which will assist managers in improving accuracy in accounting operations, transaction processing speed also increase which save time and energy. Overall, it can be said that IT system help firm in multiple ways. In contrast, There are numerous kind of risk that are mainly related with information technology such as loss of computer assets, maximized risk of fraud, mistaken record keeping, competitive disadvantages if the incorrect information technology is chosen, loss of information, business disruption and privacy violations. (Alhosban \& Al-Sharairi, 2017).

\section{Study Problem}

The fast evolution of in IT which uses computers has its impact on accounting as well as management systems of an organization. This was followed by an essential alteration within the research methodology, methods, systems auditing, internal and external oversight, this has also affected the personal configuration and training of people compared with what the matter was under the traditional way of manual data entry, (Alqtish, Alqirem and Kasem, 2018). In Jordan there is a gap in research bodies that investigate the impact of computerized auditing in reducing audit risks among audit firms.

In this research we will try to answer the following questions.

1. What are the types of computerized auditing programs that are used in Jordanian audit firms?

2. What is the importance of employees training on computerized auditing programs in Jordanian audit firms?

3. What is the impact of using computerized auditing programs in reducing audit risks?

\section{Study Objectives}

Computerized audit that is being prepared according to certain accounting policies "as defined by the ICAS" aims to help the auditor to express his opinion about it.

The research aims to:

- Identify types of computerized auditing programs that are used in Jordanian audit firms. 
INTERNATIONAL JOURNAL OF ACADEMIC RESEARCH IN BUSINESS AND SOCIAL SCIENCES

Vol. 10, No. 6, June, 2020, E-ISSN: 2222-6990 @ 2020 HRMARS

- Identify the importance of employees training on computerized auditing program in Jordanian audit firms.

- Identify the impact of using computerized audit programs in reducing audit risks in Jordanian audit firms.

\section{Study Hypotheses}

In light of the problem and objectives of research, the following hypotheses were formulated:

H01: There is no statistically important relationship between using computerized auditing program types and reducing audit risks.

H02: There is no statistically significant relationship between employees training on the computerized audit programs and reducing audit risks.

H03: There is no statistically significant relationship between using computerized audit programs and reducing audit risks.

\section{Theoretical Framework and Previous Studies}

The ICT is very important in modern business organizations in support of achieving short as well as long term objectives. (Alqudah, Amran and Hassan, 2019), Stated that the technology has been a significant tool in almost all human activity. The influence of Information technology within business organization has developed exponentially within recent years, varying the procedure of audit and outputting in both challenging and opportunities for auditors.

A study was conducted by (Al-Rahamneh, 2016), studied the effect of automated accounting systems over audit risk management within public organizations in Kisumu County. Evolution in information technology has had a dramatic impact over accounting facts machine. At the same time as computer systems end up lesser, faster, easier in the direction of the use as well as much less comfortable, the computerization of accounting function develops all the way through the entire financial carrier sector. The result is massive, at the same time as indicated via the coefficient of audit threat administration is significantly associated to evaluation and identification of hazard, monitoring along with assessment manage awareness, attitude, belief and generation. The tested system risk factors recognized essential areas of records device hazard to be the risk of breaches within system security as well as the danger that the records provided by means of the device is inadequate and the systems nature threat components identified linked through the ones risk, in order to address systems risks components, auditors require to analysis their ERP methods.

\section{Information Systems Auditing}

IT function is accountable for scheming, developing and keeping many of controls on business processes of an organization.

IT has a significant role in gathering, processing as well as storing information that is described and reported within financial statements (Alslihat and et. al. 2018).

\section{IT Auditing}

Information technology audit refers to the process of collecting as well as evaluating information based on which an individual can estimate the performance of information technology systems, i.e., to find out whether the information systems operations within the function of protecting the property and keep the integrity of data, (Al-Tarawneh, Humeedat, 2020) 
Although there is no ordinary worldwide description of information system audit (Hassan \& Marston, 2019), has explained information system audit is introduced to the process under which evidence are collected and evaluated to great extent to identify whether computer system (IS) protect data and rightly make use of available resource.

(Alzoubi, 2018), has defined IS audit as "it is the procedure whereby controls of the entire system are evaluated in proper manner. In this process reporting of efficiency level system effectiveness and practices is done to communicate about data integrity. In the audit reporting is also done about policy and rules in respect to use of system." (Amoush, 2019), As an output, business risk maximize. IT auditing is mainly needed in the company to ensure that IT system is secure and there are sufficient internal controls and make certain that assets managed by way of those structures are appropriately safeguarded. The assessment of IS and IT by auditors has generated the time period IT auditing. IT auditing is the evaluation of IT, practices, and operations to assure the integrity of an entity's data. Such assessment can include evaluation of the performance, effectiveness, and economy of pcprimarily based practices. This entails the usage of the laptop as an audit 20 device. The assessment need to also decide the adequacy of internal controls within the IT environment to assure legitimate, dependable, and relaxed records services. The Computer auditor's evaluation of systems, practices, and operations may include one or both of the following:

- Evaluation of entire control system that exists within IT environment of the company and to ensure legality, consistency, and safety of data.

- Evaluate capability of the company IT system in monetary terms (Bshayreh, Tawaha and AlKhasawneh, 2019).

\section{Objectives of IT Auditing}

One of the main objectives of information technology auditing is to evaluate whether or not an information System is meeting to the stated objectives of company and to make sure that the system is not developing an intolerable level of hazard for the organizations. The terms "attestation," "audit," and "control" typically point out same thing, however, context wise meaning of these three become different. Thus, every time they can be used interchangeably. One of the major advantages of using IT audit is that by using it one with full confidence can ensure that IT system is working efficiently and effectively, in order to identify whether IT system work efficiently one check whether inputs are generating accurate outputs correctly. It can be ensured that only one that has permission can access IT system (Hussin, Saleh and Al-smady, 2019).

IT auditing feature is essentially a support function for the attainment of conventional audit targets. As has been described in advance, that IT auditing is the entire procedure where data is first gathered and then it is evaluated in proper manner to ensure data integrity. If data will be accurate then in that case more accurately decisions can be made by the managers at the workplace.

\section{The Need for the IT Audit Function}

Computer technology is an essential and important for an organization because it will help them in their financial transaction easily. With the elevated reliance on computer systems to carry out each day transactions and with the higher dangers related to new generation, control wishes assurance that the controls governing its pc operations are good enough. The Top Ten Reasons for the Start Up of IT Auditing: 
INTERNATIONAL JOURNAL OF ACADEMIC RESEARCH IN BUSINESS AND SOCIAL SCIENCES

Vol. 10, No. 6, June, 2020, E-ISSN: 2222-6990 @ 2020 HRMARS

1. Auditing in the order of the computer was flattering unacceptable for the reason of information reliance.

2. Dependence on controls was flattering extremely questionable.

3. Financial organizations were losing cash because of creative programming.

4. Payroll databases might not be depended on for accurateness because of sophisticated Programmers.

5. The data security might no longer be compulsory effectively.

6. Advancements occurred within technology.

7. Internal networks were being accessed by employees' desktop computers.

8. Personal computers became easy to get for office as well as home use.

9. Large amounts of information needed advanced software programs in the direction of audit, known as CAATs.

The tremendous expansion of corporate hackers, moreover internal or external, necessary the need for IT auditors, (Lowe, Bierstaker, Janvrin and Jenkins, 2018).

\section{The Structure of an IT Audit}

The information technology Audit is usually classified into 3 parts which are audit planning, substantive testing and test of control (Tiberius \& Hirth, 2019). These parts will be explained as below:

\section{Audit Planning}

The primary step within information technology audit is known as auditing planning. Before the assessor conduct IT audit plan, it must hold meeting with the company officers and must try to find out information about client business so that in better way IT audit can be done. Factor that needs to be taken into account is that core portion this phase of audit is the analysis of audit risk. In this stage auditor also try to gather other facts and details so that it can conduct in better way at the workplace. Analysis of risk during audit process helps one in getting background of the company's practices, policies and structure. At this phase of audit, the inspector also determines the financially important applications as well as attempts to know the control on the primary.

There are some tools and techniques of gathering information about the topic are questionnaires, interview, observation, focus group, modeling etc. all these are effective and important but for collecting data about the existing research topic, questionnaire will be applied by investigator because it will support them in collection and analyzation of reliable data about the topic.

\section{Test of Controls}

Main purpose of test of control stage is to find out whether sufficient interior controls are within the place as well as functioning correctly. In order to attain this, the assessor performs different number of tests of controls. The confirmation collecting tool followed at this stage may cover both specialized computer audit techniques and manual technique.

Auditor after completion of entire testing must prepare a conclusion about the control phase. In other words, it can be said that, the auditor should evaluate the quality of the internal controls.

\section{Substantive Testing}

The third segment of the audit method focuses on the monetary data. This involved a detailed investigation of particular account balances and transaction thru what are known as major 
assessments. Some sizeable exams are bodily, labor in depth sports consisting of counting coins, counting inventories within the warehouse, and verifying the life of inventory certificates in a safe. In an IT surroundings, the records had to carry out sizeable checks (which include account stability and name and addresses of individual customers) is contained in information files that often need to be extracted the use of (CAATTs) software.

\section{Assessing Audit risk and designing tests of controls}

One of the main risks associated with the audit outcome is that there are chances that auditor may provide an incorrect view on the financial statements that are prepared by an organization accountant. Auditor may state that materials are misstated. Material misstatement might be caused by irregularities or errors or both. Errors are accidental errors. Irregularities are intentional misrepresentations to deceive customers of the accounting information. Main purpose behind such act is to maintain confidence of stakeholders on the company. Auditors always try or make an attempt to reduce audit risk by carrying out multiple tests at the workplace (Lowe, Reckers and Sauciuc, 2018).

\section{Audit Risk Components}

Audit risk: The risk that the examiner may innocently fail in the direction of modifies his or her view on financial account that is significantly misstated. By the side of the account balance otherwise class of transactions plane, it includes of the material misstatement risk, and detection risk. There are some components of risks which will be described as below:

1. Planned detection risk

It is the sort of risk where there is probability that auditor may fail to find out anything wrong in the accounts. Small mistakes if remain untracked then it is not a big issue but if any big mistake remain unidentified then in that mistake made by auditor may be considered intolerable. It is well known fact that PDR fixes the amount of substantial evidence that the auditor plan to accumulate, inversely with the scale of planned detection risk. It is commonly assumed that in case if PDR decline then in that case one requires collecting more evidence to achieve reduced planned risks, (Mansour, 2016). 2. Inherent risk

It is usually stated that inherent risk introduces to the situation where probability of loss comes in existence before considering any risk-reducing factors. During process of evaluation of inherent risk, experienced professional need to find out taken into account variety of risks as well as elements that reflect that a risk exists. Thus, auditor needs to be more familiar with the company and its business details, (McCamley, Vivantiand Edirippulige, 2019).

3. Control Risk

It is very important risk and, in this control, risk evaluate auditor assessment if presentation of any wrong fact in the financial statements cross a limit of threshold level in a segment and whether it can be distinguished on a well-timed by the internal control of clients. In this auditor always assume that internal control of the firm is very week and unproductive to stop or detect misstatements.

4. Acceptable audit risk

Is a degree of the way inclined the auditors is to simply accept that the monetary announcement May be materially misstated after the audit is completed and an unqualified opinion has been issued? When auditors decide on lower perfect audit threat, they need to ensure that the announcement of 
INTERNATIONAL JOURNAL OF ACADEMIC RESEARCH IN BUSINESS AND SOCIAL SCIENCES

Vol. 10, No. 6, June, 2020, E-ISSN: 2222-6990 @ 2020 HRMARS

financial position, announcement of income and statement of cash flows aren't material misstated (Srour and Yorke-Smith, 2016).

\section{Methodology}

There are basically two approaches of scientific research methods which are used as a methodology of this study, the first one is the Descriptive and analytical approach, and this approach has been used for the literature review to explore the impact of computerized auditing programs in reducing audit risks in Jordanian audit firms. The second Research Methodology Field has been used to cover the sensible side of this study, through trying out the validity of hypotheses of the have a look at, and answering questions, and drawing their effects out of the questionnaire that changed into organized for the studies examine by way of considering steps of scientific norms.

\section{Study Population}

The study population consisted of all accountants in the top ten audit firms in Jordan.

\section{Study Sample}

Within an investigation, random sampling method has been followed by researcher because it not takes more time. It has been the study sample of accountants in the top ten audit firms in Jordan, the researcher distributed (60) questionnaire, and after retrieving questionnaires were excluded (10) questionnaires for non-suitability for the reason of statistical analysis, the research sample final entirely (50) questionnaire, and the Table (1) shows the demographic distribution of the study sample.

Table (1) Demographic distribution of the study sample

\begin{tabular}{|c|c|c|}
\hline Variable & Repetition & Percentage \\
\hline \multicolumn{3}{|c|}{ Sex } \\
\hline Male & 34 & $68 \%$ \\
\hline Female & 16 & $32 \%$ \\
\hline \multicolumn{3}{|c|}{ Age } \\
\hline $26-25$ & 20 & $40 \%$ \\
\hline $36-35$ & 18 & $36 \%$ \\
\hline 46 \& above & 7 & $14 \%$ \\
\hline \multicolumn{3}{|c|}{ Academic Qualification } \\
\hline High School & $* * *$ & $10 \$$ \\
\hline Diploma & 3 & $4 \%$ \\
\hline Bachelor & 35 & $70 \%$ \\
\hline Master & 13 & $26 \%$ \\
\hline Total & 50 & $100 \%$ \\
\hline
\end{tabular}

\section{Study Tool}

There are two types of study tool which have been explained as below:

First Part: Demographic Variables, including (Gender, Age, Academic qualification).

Second Part: including: 
INTERNATIONAL JOURNAL OF ACADEMIC RESEARCH IN BUSINESS AND SOCIAL SCIENCES

Vol. 10, No. 6, June, 2020, E-ISSN: 2222-6990 @ 2020 HRMARS

1. First Axis: Types of software.

2. Second Axis: Training programs.

3. Third Axis: Computerized accounting information systems.

\section{Reliability of Study Tool}

Questionnaire refers to the most essential and useful tool of measuring reliability of data. Within an investigation questionnaire has been applied by investigator for collecting reliable information about the current study. The questionnaire was submitted to arbitrator (Supervisor of the research), to confirm the honesty of its paragraphs, and to obtain his view, and re-wording of several paragraphs, and create the necessary modifications, to cautiously strike a weight quantity among the data of resolution within paragraphs, and as regarding it, which confirms the certainty of the tool.

\section{Stability of Study Tool}

In order to calculate and measure stability of research instrument, the investigator followed the equation of internal consistency with the use of test Cronbach's alpha that is displayed within Table

(2) the test output where the values of Cronbach alpha intended for all variables of an investigation and recognition of usually higher (60\%) that is satisfactory within investigation and studies.

\section{Statistical Processing}

In order to answer all questions within the research, analytical and descriptive methods have been used by researcher with the use of SPSS. It includes standard descriptive statistics (Descriptive Statistic Measure), to explain the uniqueness of the sample relaying on the, percentages, frequencies and to respond the research questions, standard deviations, means as and Cronbach Alpha Test will be applied by researcher to make sure the stability of investigation tool as well as testing of One Sample T-test.

\section{Testing Hypotheses}

H01: There is no statistically significant relationship between using computerized auditing program types and reducing audit risks.

To answer the first hypothesis was extracted averages and standard deviations to identify the responses of the sample of the study about the importance of the types of programs that are used in the computerized audit, and Table (2) illustrates that.

Table (2) The arithmetic means, standard deviations and the materiality for the first axis (the types of programs that are used in the computerized audit). 
INTERNATIONAL JOURNAL OF ACADEMIC RESEARCH IN BUSINESS AND SOCIAL SCIENCES Vol. 10, No. 6, June, 2020, E-ISSN: 2222-6990 @ 2020 HRMARS

\begin{tabular}{|c|l|c|c|c|c|}
\hline No & Paragraph & Means & $\begin{array}{l}\text { Standard } \\
\text { deviation }\end{array}$ & $\begin{array}{l}\text { Relative } \\
\text { Important }\end{array}$ & Rank \\
\hline 2 & $\begin{array}{l}\text { The computerized programs to save } \\
\text { work on a daily basis. }\end{array}$ & 4.22 & 0.86 & High & 1 \\
\hline 1 & $\begin{array}{l}\text { Modern computerized programs used } \\
\text { in computerized accounting audit. }\end{array}$ & 4.16 & 1.02 & High & 2 \\
\hline 5 & $\begin{array}{l}\text { The process input the wrong threat to } \\
\text { the computerized audit results. }\end{array}$ & 4.04 & 1.24 & High & 3 \\
\hline 4 & $\begin{array}{l}\text { Programs are exposed to the entry of } \\
\text { viruses pose a threat to the accounting }\end{array}$ & 4.00 & 1.32 & High & 4 \\
\hline 3 & $\begin{array}{l}\text { Information. } \\
\text { accurately in the event of loss. }\end{array}$ & 3.06 & 1.53 & Medium & 5 \\
\hline & General average & 3.90 & 1.20 & High & \\
\hline
\end{tabular}

Seen from the Table (2) that the averages for this axis (the types of programs that are used in auditing computerized), ranged between (4.22 and 3.06), where he earned axis on the arithmetic average total (3.90), a high level, and has received Paragraph No. (2) the highest average account where the (4.22), and the standard deviation (0.86), a high level, which stipulates paragraph (the computerized programs to save work on a daily basis), and in second place came paragraph (1) with a mean (4.16) and standard deviation (1.02), a high level, which stipulates that paragraph (a modern computerized programs used in computerized accounting audit ), On the contrary the number of paragraph (3) in the last place where won the arithmetic average (3.06), and a standard deviation (1.53), a mid-level, which stipulates that paragraph (information can be retrieved accurately in the event of loss).This explains that the software used in the computerized audit and ensure good financial performance well.

H02: There is no statistically significant relationship between employees training on the computerized audit programs and reducing audit risks.

To answer the second hypothesis descriptive statistics tools used are averages and standard deviations which help to evaluate results of the research study that is about the importance of the types of training programs for staff in the computerized audit program in reducing audit risks in Jordanian audit firms, and Table 3 illustrates that.

Table (3): The arithmetic means, standard deviations and the materiality for the second axis (training programs). 
INTERNATIONAL JOURNAL OF ACADEMIC RESEARCH IN BUSINESS AND SOCIAL SCIENCES Vol. 10, No. 6, June, 2020, E-ISSN: 2222-6990 @ 2020 HRMARS

\begin{tabular}{|c|c|c|c|c|c|}
\hline No & Paragraph & Means & $\begin{array}{l}\text { Standard } \\
\text { deviation }\end{array}$ & $\begin{array}{l}\text { Relative } \\
\text { Important }\end{array}$ & Rank \\
\hline 6 & $\begin{array}{l}\text { Hold special training courses to } \\
\text { programs that are used in the } \\
\text { computerized audit. }\end{array}$ & 4.44 & 0.70 & High & 1 \\
\hline 7 & $\begin{array}{l}\text { Coaching staff commensurate with } \\
\text { their qualifications and their ability to } \\
\text { handle errors occurring in } \\
\text { computerized financial information. }\end{array}$ & 4.40 & 0.88 & High & 2 \\
\hline 8 & $\begin{array}{l}\text { Staff training to save programs from } \\
\text { any computer breakthroughs }\end{array}$ & 3.96 & 1.09 & High & 3 \\
\hline 9 & $\begin{array}{l}\text { Work on the protection of computer } \\
\text { systems for the computerized audit. }\end{array}$ & 3.92 & 1.12 & High & 4 \\
\hline 12 & $\begin{array}{l}\text { Training programs provide accountants } \\
\text { with sufficient information to lead work } \\
\text { well. }\end{array}$ & 3.81 & 1.16 & High & 5 \\
\hline 11 & $\begin{array}{l}\text { Training courses to help solve problems } \\
\text { with accountants. }\end{array}$ & 3.75 & 1.20 & High & 6 \\
\hline 10 & $\begin{array}{l}\text { Training courses serve the desired } \\
\text { goals, used in computerized audit. }\end{array}$ & 3.57 & 1.29 & High & 7 \\
\hline & General average & 3.98 & 1.06 & High & \\
\hline
\end{tabular}

Table No. (3) showed that the averages for this axis (training programs), ranged between (4.44 and 3.57), where he earned axis on the arithmetic average total (3.98), a high level, and has received Paragraph (6) on top arithmetic average reaching (4.44), and the standard deviation (0.70), a high level, which stipulates paragraph (holding training courses for the programs that are used in auditing computerized), and in second place came paragraph (7) with a mean (4.40) and deviation standard (0.88), a high level also, which stipulates that paragraph (coaching staff commensurate with their qualifications and their ability to handle errors occurring in computerized financial information). Came in ranked last paragraph (10) reached a mean (3.57), and a standard deviation (1.29), where the Paragraph (training courses serve the desired goals, used in computerized audit). This explains that the staff are well trained and fully qualified for the work of the accounting and auditing computerized ensuring impress.

H03: There is no statistically significant relationship between using computerized audit programs and reducing audit risks.

To answer the third hypothesis descriptive statistics tools used are averages and standard deviations which help to evaluate results of the research study that is regarding the significance of the role of IS in computerized accounting audit computerized financial institutions and companies of Jordan, and Table (4) illustrates that.

Table (4): The arithmetic means, standard deviations and the materiality for the third axis (Accounting Information Systems) 
INTERNATIONAL JOURNAL OF ACADEMIC RESEARCH IN BUSINESS AND SOCIAL SCIENCES Vol. 10, No. 6, June, 2020, E-ISSN: 2222-6990 @ 2020 HRMARS

\begin{tabular}{|c|c|c|c|c|c|}
\hline No & Paragraph & Means & $\begin{array}{l}\text { Standard } \\
\text { deviation }\end{array}$ & $\begin{array}{l}\text { Relative } \\
\text { Important }\end{array}$ & Rank \\
\hline 14 & $\begin{array}{l}\text { Accounting information systems are } \\
\text { connected quickly with accounting and } \\
\text { information technology. }\end{array}$ & 4.34 & 0.77 & High & 1 \\
\hline 15 & $\begin{array}{l}\text { Many of the traditional functions } \\
\text { include accounting systems require a } \\
\text { mixture of new technological } \\
\text { knowledge and accounting. }\end{array}$ & 4.20 & 0.95 & High & 2 \\
\hline 16 & $\begin{array}{l}\text { Systems should be able to apply } \\
\text { software development and } \\
\text { improvement produced in accounting. }\end{array}$ & 3.64 & 1.14 & High & 3 \\
\hline 13 & $\begin{array}{l}\text { Define pages and tables and specific } \\
\text { accounting software, and explained } \\
\text { and integration application of } \\
\text { information technology. }\end{array}$ & 3.34 & 1.12 & Medium & 4 \\
\hline 17 & $\begin{array}{l}\text { Facilitate the provision of accounting } \\
\text { information systems in the centers and } \\
\text { institutions concerned with the } \\
\text { accounting audit. }\end{array}$ & 3.31 & 1.13 & Medium & 5 \\
\hline 18 & $\begin{array}{l}\text { Easy to deal with accounting } \\
\text { information systems. }\end{array}$ & 3.29 & 1.15 & Medium & 6 \\
\hline 19 & $\begin{array}{l}\text { Speed in the application of accounting } \\
\text { information systems. }\end{array}$ & 3.01 & 1.25 & Medium & 7 \\
\hline 21 & $\begin{array}{l}\text { Accounting information systems } \\
\text { interfere with each other with respect } \\
\text { to the accounting programs in terms of } \\
\text { tariffs. }\end{array}$ & 2.29 & 1.35 & Low & 8 \\
\hline 20 & $\begin{array}{l}\text { Accounting information systems are } \\
\text { available in abundance in the local } \\
\text { markets. }\end{array}$ & 2.25 & 1.40 & Low & 9 \\
\hline & General average & 3.30 & 1.14 & Medium & \\
\hline
\end{tabular}

Table No. (4) showed that the averages for this axis (Accounting Information Systems), ranged between (4.34 and 2.25), where he earned axis on the arithmetic average total (3.30), a mid-level, and has received Paragraph (14) on the highest average account where the (4.34), and the standard deviation (0.77), a high level, which stipulates paragraph (accounting information systems are connected quickly with accounting and information technologies), and in second place came paragraph (15) with a mean (4.20) the standard deviation (0.95), a high level also, which stipulates that paragraph (many of the traditional functions include accounting systems require a mixture of new technological knowledge and accounting) .In contrast, came in ranked last paragraph number (20) came in as the last award was the arithmetic average (2.25), and a standard deviation (1.40), where the Paragraph (easy to deal with accounting information systems) .This explains that the accounting information systems used in financial companies Jordanian reduce risks and accounting with an average level and ensure good performance. 


\section{Conclusion}

This study aims to identify the impact of computerized auditing in reducing audit risks in Jordan. By testing the hypotheses, the study reached the following results:

1. There is a statistically significant relationship between the types of programs that are used in the computerized audit and financial performance in the financial institutions and companies in Jordan. The results attained in this respect includes saving of work on a daily basis by computerized program, modern computerized programs used in computerized accounting audit and information can be retrieved accurately in the event of loss. This means that that the software used in the computerized audit ensure good financial performance.

2. There is a statistically significant relationship between the types of training programs for staff in the computerized audit and financial performance in the financial institutions and companies in Jordan. The results attained in respect to the same are holding training courses for the programs that are used in auditing computerized; coaching staff commensurate with their qualifications and their ability to handle errors occurring in computerized financial information and training courses serve the desired goals, used in computerized audit. Finally, this demonstrates that staff are well trained and fully qualified for the work of the accounting and auditing computerized ensuring impress.

3. There is a statistically significant relationship between accounting information systems in the computerized audit and financial performance in the financial institutions and companies in Jordan. The results attained in this respect includes accounting information systems are connected quickly with accounting and information technologies, many of the traditional functions include accounting systems require a mixture of new technological knowledge and accounting and easy to deal with accounting information systems. Ultimately, this depicts that the accounting information systems used in financial companies Jordanian reduce risks and accounting with an average level and ensure good performance.

\section{Suggestions}

These are the recommendations for the purpose of improving computerized audit within Jordan. The successful implementation of these must help the all organizations that improve their recording of transactions so the risk related to audit will be minimized. The different suggestions in respect to same are provided below:

1. Implementation of application controls within their units. These are the controls that relates to the transaction as well as standing information pertaining in the direction of a computer based accounting system. These are specific toward known application in addition to having the main objective related to completeness and accuracy of the accounting records along with the validity of entries which are made under such records. This help in safeguarding the risk of material misstatement.

2. Implementation of input controls within their systems. In this, control activities are designed in such way that ensuring the input is authorized, accurate, complete and timely. These controls vary according to the terms of quantity and sophistication of matters. The determinants which are considering under this includes cost considerations and confidentiality requirements with regard to the data input. The various aspects in which this provides the further assistance are rage checks, validity checks, format checks, sequence checks, control totals, check digit verification etc.

3. Implementation of the processing controls within the institutions. This has the work related to ensuring that input data will be processed correctly along with all the data files updated accurately 
in timed manner. The different functions performed with aid of this includes run to run controls, ensuring the integrity of cumulative totals that are contained within the accounting records which is ascertained from the processing of one data to the next. Some other basic aspects in which this assists include appropriate investigation in respect to the rejected items and evidencing that reject errors have been corrected properly and re-input within the records.

\section{Theoretical and Contextual Contribution of the Research}

Theoretical contribution refers as a systematic process which is mainly based on the theory advancement and development in existing theory by means of some logics and details. The answers for these questions in theoretical studies will improve the impact of paper as well as enhance the chance of publication.

Use of computer based AIS has become extensive within entire organization. Use of information technology at that time was restricted only to transaction system. It also recommended that information technology skills and knowledge are essential for accountants, mutually with their business knowledge and skill for successful development of computerization of accounting within their business organization.

Along with this, this research is important at academic as well as individual level. At cadmic level, this research or topic helps students by increasing their understanding regarding the types of computerized auditing programs that are used in within an organization, importance of employees training on computerized auditing program and the impact of using computerized audit programs in reducing audit risks in firms. Apart from this, if this research is published, it will be beneficial for individual, organization and also society because it will help them in increasing their understating about the computerized auditing and its significance in reduction of audit risks. This research is also essential at personal level because it support researcher or an individual by improving their research skills such as review of literature, collection of data, analyzing of data, time management etc. With the use of these skills they can easily attain better outcomes for the study. Main role of this research is to increase awareness about the computerized auditing and its importance in reduction of audit risks. Therefore, with the help of this research, an individual can easily learn about the significance of computerized auditing for an organization. This is important for firm by saving their time and also providing accurate information about the business audit.

\section{References}

Al-Akra, M., Abdel-Qader, W., \& Billah, M. (2016). Internal auditing in the Middle East and North Africa: A literature review. Journal of International Accounting, Auditing and Taxation, 26, 1327.

Alhosban, A. A., \& Al-Sharairi, M. (2017). Role of internal auditor in dealing with computer networks Technology-Applied study in Islamic banks in Jordan. International Business Research. 10(6). 259-269.

Alqtish, A., Alqirem, R., \& Kasem, F. (2018). The Impact of Electronic Tax Auditing on the Reduction of Tax Evasion from the Perspective of the Income and Sales Tax Department in Jordan. Journal of Accounting, Finance \& Management Strategy, 13(1).

Alqudah, H. M., Amran, N. A., \& Hassan, H. (2019). Factors affecting the internal auditors' effectiveness in the Jordanian public sector. EuroMed Journal of Business. 
INTERNATIONAL JOURNAL OF ACADEMIC RESEARCH IN BUSINESS AND SOCIAL SCIENCES

Vol. 10, No. 6, June, 2020, E-ISSN: 2222-6990 @ 2020 HRMARS

Al-Rahamneh, L. S. (2016). The impact of computerized information systems on the compliance of internal control requirements according to ISA (315) in Jordanian Companies from the perspectives of their employees. International Journal of Economics and Finance. 8(9). 156172.

Al-Tarawneh, A., Weshah, S., \& Humeedat, M. (2020). The Extent of External Auditor Relaying on Internal Auditor Work under Erp Continuous Auditing: The Case of Jordan. Academy of Accounting and Financial Studies Journal. 24(2). 1-9.

Alzoubi, E. S. S. (2018). Audit quality, debt financing, and earnings management: Evidence from Jordan. Journal of International Accounting, Auditing and Taxation. 30. 69-84.

Amoush, A. H. (2019). Using Information Technology among Auditors in Jordan. International Research Journal of Applied Finance. 10(3). 109-114.

Bshayreh, M. M., Tawaha, M. S., \& Al-Khasawneh, R. O. H. (2019). The Effect of Electronic Management in Improving the Quality of Internal Audit through Developing the Performance of Internal Auditor: An Empirical Study in the Jordanian Insurance Companies. Academy of Accounting and Financial Studies Journal.

Hassan, O. A., and Marston, C. (2019). Corporate Financial Disclosure Measurement in the Empirical Accounting Literature: A Review Article. The International Journal of Accounting. 54(02), pp 1-24. Doi/abs/10.1142/S1094406019500069.

Hussin, S. A. H. S., Saleh, N. M., \& Al-smady, A. A. (2019). Auditor Demographic Factors and Dimensions of Auditors' Skepticism in Jordan. Asian Journal of Accounting and Governance, 11.

Lowe, D. J., Bierstaker, J. L., Janvrin, D. J., \& Jenkins, J. G. (2018). Information Technology in an Audit Context: Have the Big 4 Lost Their Advantage? Journal of information systems. 32(1). 87-107.

Lowe, D. J., Reckers, P., \& Sauciuc, A. (2018). Mitigating the Effect of Rationalizations on Ethical Accounting Decisions.

Mansour, E. M. (2016). Factors affecting the adoption of computer assisted audit techniques in audit process: Findings from Jordan. Business and Economic Research. 6(1). 248-271.

McCamley, J., Vivanti, A., \& Edirippulige, S. (2019). Dietetics in the digital age: The impact of an electronic medical record on a tertiary hospital dietetic department. Nutrition \& Dietetics, 76(4), 480-485.

Salihu, A., \& Berisha-Hoti, X. (2019). The Effect of IT Audit on Security Incidents. International Journal of Scientific \& Technology Research 8(8):1342-1347

Srour, F. J., \& Yorke-Smith, N. (2016). Assessing maritime customs process re-engineering using agent-based simulation.

Tarek, M., Mohamed, E. K., Hussain, M. M., \& Basuony, M. A. (2017). The implication of information technology on the audit profession in developing country. International Journal of Accounting \& Information Management.

Tiberius, V., and Hirth, S. (2019). Impacts of digitization on auditing: A Delphi study for Germany. Journal of International Accounting, Auditing and Taxation. Elsevier, vol. 37(C). DOI: 10.1016/j.intaccaudtax.2019.100288. 